\title{
4 Main Aspects of the Stakeholders' Approach Evolution
}

\section{Short History of the Stakeholders' Approach}

The beginning of the stakeholders' approach dates back to before the Second World War. In 1932, the General Electric Company identified four groups with whom they had to deal: shareholders, employees, customers, and the general public. In 1947, Johnson \& Johnson identified customers, employees, managers, and the general public. In 1950, the Sears Company named four parties that are very important for any business - customers, employees, the community, and stockholders (Fontaine, Haarman, \& Schmid, 2006). Later, in 1963, according to Freeman (1984), in an internal report by the Stanford Research Institute, the first definition of stakeholders was formulated as "those groups without whose support the organization would cease to exist". Stewart and Benepe, who worked with the Stanford Research Institute and Lockheed Aircraft, also deal in some way with the subject of stakeholders (Chartered Management Institute, 2013).

The information regarding the beginning of the stakeholders' approach, until the book by Freeman (1984), describes what we consider could be referred to as the "stakeholders' prehistory approach".

The "real" history of the stakeholders' approach starts with Freeman's landmark book (1984), in which he lays down the basic elements regarding the stakeholder concept. In this book, Freeman states that an organization should be thought of as grouping stakeholders and the purpose of the organization should be to manage their interests, needs, and viewpoints. He tried to build a framework capable of responding to the concerns of managers, who were being confronted with unexpected and high levels of environmental turbulence and change. This framework is based on the stakeholder concept. Freeman suggested that company managers must elaborate and implement processes capable of satisfying those groups who have a stake in the business. Later, Freeman generated another important contribution to the stakeholders' approach - the four types of stakeholders' strategy (offensive, defensive, swing, and hold).

DOI: $10.4324 / 9781003217701-4$ 
A very important contribution was made by Donaldson and Preston (1995) in the study "The Stakeholder Theory of the Corporation: Concepts, Evidence and Implications", where they grouped the stakeholders' theory literature in three fields, namely descriptive, instrumental, and normative, and they argued that "stakeholders theory is managerial" and recommended "the attitudes, structures and practices that taken together constitute a stakeholder managerial philosophy".

In 1997, Mitchell, Agle, and Wood elaborated a model based on three criteria - stakeholders' power to influence a company, the legitimacy of the stakeholders' relationship with the company, and the urgency of the stakeholder claim of the firm - which led to seven stakeholder types very useful for company management in order to prioritize stakeholders' relationships. They contributed significantly to the elaboration of the theory of stakeholder identification and salience.

Elias and Cavana (2000) from New Zeeland, using some ideas from Freeman's works, launched the concept "stakeholder dynamics", very useful for realistic and performant management of the company-stakeholder strategic relationship.

A few years later, Friedman and Miles (2002) made very relevant contributions to the stakeholder theory development by creating a special typology of organization-stakeholder relationships (type A, type B, type $\mathrm{D}$, and type $\mathrm{E}$ ), based on two distinctions: compatible/incompatible and necessary/contingent.

Steurer (2006), based on the triple-perspective typology of the stakeholder theory, formulated nine stakeholder approaches, which allows us to frame the contributions of the specialists in the field and to evaluate their impacts on three levels - corporate, stakeholder, and conceptual.

Corporate social responsibility, based largely on Carroll's pyramid (Carroll, 1979), promotes a vision of business accountability to a large range of stakeholders (e.g. Baden, 2016; Carroll, 1991; Chandler \& Werther, 2014). Corporate social responsibility refers to the society's expectations - economic, legal, and ethical - of organization stakeholders.

Harrison and Wicks (2013) conceived a stakeholder-based perspective on value, which focuses on four factors that emerge in the context of the company-stakeholder relationships: stakeholder utility, associated with actual goals and services; stakeholder utility, associated with organizational justice; stakeholder utility, from affiliation; and stakeholder utility, associated with perceived opportunity costs.

Garcia-Castro and Aguilera (2015) developed a conceptual framework based on an analytical taxonomy of value creation and appropriation consistent with a more complete notion of value and wherein the trade-off in stakeholder value appropriation could be included in a world with multiple stakeholders.

Observing that in theory and practice, social welfare appears to be a multidimensional and pluralistic concept, Mitchell, Weaver, Agle, Bailey, 


\section{2}

and Carlson (2015) developed an account of multi-objective corporation as a means for enabling a greater range of management decisions and actions, in order to permit more direct organization engagement in the diverse goals of different stakeholders. They argued the consistent advantages of multi-objective corporation, compared with a singleobjective corporate function.

Recently, Miles (2017) conducted an analysis via an unparalleled bounded systemic review of 593 stakeholder definitions and produced a comprehensive, multidimensional classification of stakeholder theories, based on four hyponyms, which relate to 16 definitional categories. Her conclusion is that stakeholder theory is indeed a single theory.

Another very interesting approach was presented by Berman and Johnson-Cramer (2017), who analyzed whether stakeholder theory constitutes an established academic field. Their answer is both "yes" and "no", and they outline future directions for stakeholder research.

In the same period, Edward Freeman, "the father" of the modern stakeholders' approach, published a study in which he suggests that there are at least five main challenges to the development of stakeholder theory: understanding what counts as the total performance of a business; accounting for stakeholders, rather than accounting for investors; explaining real stakeholder behaviour; formulating smart public policy in the light of stakeholder theory; and rethinking the basics of ethical theory (Freeman, 2017).

Recently, in the context of the COVID-19 pandemic, we have seen that the focus on the role of stakeholders continues. Many approaches (Levenson, 2020; Narayandas, Hebbar, \& Li, 2020; Radjou, 2020; Romeo, Moukanas, \& Rung, 2020; Tarabishy \& Carayannis, 2020; Teece, Raspin, \& Cox, 2020; World Economic Forum, 2020) stress the increasing need to take into consideration organizations' stakeholders in order to solve better the complex challenges and difficulties associated with the COVID-19 pandemic and relaunch the economy.

Finally, we would like to point out that there are many other valuable works and specialists that could be mentioned as contributing significantly to the stakeholder theory and practice development. We select only these, trying to summarize in a few pages the relevant elements from the perspective of stakeholder company management. We try to do this because we fully agree with the thesis that "stakeholder theory is a genre of management theory” formulated by Freeman, Harrison, Wicks, Parmar, and De Colle.

\section{Descriptive, Instrumental, and Normative Approaches}

Without any doubt, in the rich stakeholder literature, a central position is occupied by Donaldson and Preston's (1995) three approaches of stakeholder theory - descriptive, instrumental, and normative. This systematization is based mainly on the objectives taken into 
consideration by specialists in stakeholder analysis and the ways to achieve them.

The objective of the descriptive approach is to understand how managers deal with organizations' internal and external stakeholders, how they represent stakeholders' interests, and what their impact is on the achievement of each corporation's goals. A corporation is considered as a constellation of cooperative and competitive interests possessing intrinsic value (Lawrence, 2010). The descriptive approach helps to fulfil a realistic map of a company's stakeholder identification. The descriptive approach is an essential process (step) that is necessary in order to understand the complex relationships among the company's multiple stakeholders and how they work. Numerous empirical studies illustrate the usefulness of the descriptive approach.

The instrumental approach is focused on the relationships between managers' decisions, the actions and behaviours of the company stakeholders, and the achievement of the organization's objectives regarding profitability, growth, and sustainability. The instrumental approach deals with how company managers should act if they want to favour, and work for, their interests. The instrumental approach is essentially hypothetical. It is based on the supposition that company managers and other agents taking into consideration the stakeholders' interests will generate better company performance in the long run. There are a lot of empirical studies that support this thesis, but not all. Models based on the instrumental approach enable the testing of the connection between managing stakeholders and the accomplishment of the company's objectives and targets. In this respect, the instrumental approach is "prescriptive" too, and it has predictive value. Certain specialists (e.g. Lawrence, 2010) believe that the descriptive approach and the instrumental approach together constitute analytic theory, which answers the question of how to organize stakeholders' interests into a hierarchy.

The main objective of the normative approach is to identify moral and philosophical guidelines linked to the activity of management of corporations (Fontaine et al., 2006), supposing that stakeholders have inherent value. It is based, according to Donaldson and Preston (1995), on two "ideas":

a stakeholders are individuals or groups with legitimate interests in procedural and/or substantial aspects of corporate activity. Stakeholders are identified by their interests in a corporation, and whether the corporation has any corresponding functional interests in them;

b the interests of stakeholders are of intrinsic value; that is, each group of stakeholders merits consideration for its own sake and not merely because of its ability to further the interests of some other groups, such as shareholders. 


\section{4}

Stakeholders' Approach Evolution

The normative approach focuses on the rights and obligations of company managers and on the fairness and justice of different courses of action and behaviour (Berman \& Johnson-Cramer, 2017). The normative approach is used to interpret the function of the corporation, including the identification of moral and philosophical guidelines for the operation and management of the corporation (Donaldson \& Preston, 1995). In contrast to the instrumental approach, the normative approach is not hypothetical, but categorical. A large proportion of books and studies on stakeholders are normative (e.g. Freeman, 2017; Freeman et al., 2010; Lawrence, 2010), ${ }^{1}$ but according to some specialists in business (Zakhem \& Palmer, 2017), it is still a dominant shareholdercentric approach. In the view of Donaldson and Preston (1995), the three approaches - descriptive, instrumental, and normative - are nested within each other (Figure 4.1).

Figure 4.1 illustrates the close connection between the three approaches, which are mutually supportive, the normative approach being at the central core. From a managerial point of view, the model represented by these three interrelated approaches indicates that company managers should acknowledge the validity of different stakeholder interests and should strive to respond to them within a mutually supportive framework, generating multidimensional performance and sustainability for the organization and its stakeholders.

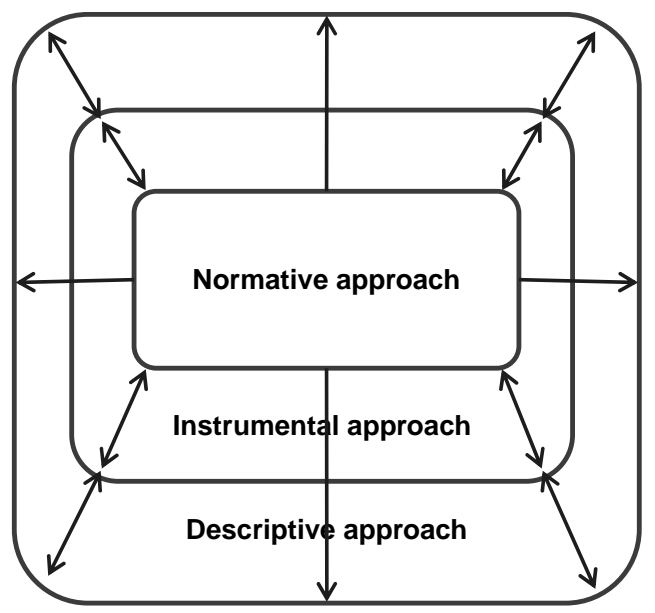

Figure 4.1 Three aspects of stakeholder theory.

Adapted from "The stakeholder theory of the corporation: Concepts, evidence, and implications" by T. Donaldson \& L. E. Preston, 1995, Academy of Management Review, 20(1), p. 74. Retrieved from https://www.jstor.org/stable/258887?seq=1\# metadata_info_tab_contents. 


\section{Main Categories of Stakeholders}

The central element in the three main approaches (descriptive, instrumental, and normative) of stakeholders in the stakeholder theory and practice is "the stakeholder concept". Its definition has been very diversified, as we have already mentioned, with almost 600 definitions of stakeholders being identified by Miles (2017). Essentially, a stakeholder is a person or group of persons who have an interest or a "stake" in an organization and the performance of that organization that affects it and could also be affected by this (Berman \& Johnson-Cramer, 2017). From this definition, it can be gleaned that stakeholders have three main characteristics:

- the person or group has an interest or a stake in the company's works and performance;

- the person or group, their decisions, actions, and behaviours, could affect the company's activities and results;

- the person or group could be affected by the company's activities and performance.

In the rich stakeholder literature, based on the different stakeholder definitions, types of approach, specific visions, and the objectives of the specialists, a large variety of stakeholder categories is presented. In the following sections, we will synthetically present some of them that are useful for better understanding company stakeholder management.

The oldest classification of stakeholders made by Freeman (1984), and the most frequently used, is based on stakeholder direct interest or stake in an organization. According to this criterion, stakeholders are divided into:

- primary stakeholders, which have a direct interest or stake in the organization and substantially affect and are affected by it;

- secondary stakeholders, which are usually public or special-interest, groups that do not have a direct stake in company but are affected by its operations and performances.

In Table 4.1, we present a list of the most frequent company stakeholders grouped in these two categories. We have elaborated this list of stakeholders, and we have divided the stakeholders into two categories, using various approaches of numerous specialists (Buchholtz \& Carroll, 2012; Chartered Management Institute, 2013; Coghlan, 2016; Freeman, 1984; Freeman et al., 2010; Harrison \& Wicks, 2013; Kumar \& Rajan, 2017; Lawrence, 2010; Miles, 2017; Mitchell et al., 1997; Steurer, 2006; Wheeler \& Sillanpää, 1997; Wheeler \& Sillanpää, 1998; Zakhem \& Palmer, 2017), who quite often are partially different. Of course, we assume responsibility for the content of this classification. 
Table 4.1 Primary and secondary company stakeholders ${ }^{2}$

\begin{tabular}{|c|c|}
\hline Primary & Secondary \\
\hline $\begin{array}{l}\text { - Stockholders } \\
\text { - Top managers } \\
\text { - Employees (executants) } \\
\text { - Customers (strategic) })^{3} \\
\text { - Suppliers (strategic) } \\
\text { - Investors } \\
\text { - Business partners (strategic) } \\
\text { - Communities } \\
\text { - Natural environment } \\
\text { - Future generation }\end{array}$ & $\begin{array}{l}\text { - Local, territorial and central govern- } \\
\text { - Mental bodies } \\
\text { - Codia } \\
\text { - Regulatory bodies } \\
\text { - Inspection bodies } \\
\text { - Competitors } \\
\text { - Consultants } \\
\text { - Trainers } \\
\text { - Designers } \\
\text { - Trade unions } \\
\text { - Employers' organizations } \\
\text { - Civic groups }\end{array}$ \\
\hline
\end{tabular}

Certain specialists have identified different subcategories within primary stakeholder groups. For example, Wheeler and Sillanpää (1997) grouped primary stakeholders into:

- primary social stakeholders (shareholders and investors, managers and employees, customers, etc.);

- primary non-social stakeholders (natural environment, future generation, etc.).

In Table 4.2, we list other stakeholder classifications, which could be useful in the management of company stakeholders.

Each stakeholder category involves a specific approach from the company's management in order to valorize their potential and to reduce or eliminate the negative impact.

\section{Stakeholder Identification and Prioritization}

From a managerial point of view, one of the most important and difficult aspects regarding company stakeholders is their identification and prioritization. In the stakeholder literature, there are many approaches to this aspect. Without any doubt, the salient model elaborated by Mitchell et al. (1997) is the best known. They identified three essential attributes regarding stakeholders:

- power (the impact of the individual or group stakeholder on the organization);

- legitimacy (the legitimacy of the stakeholder claim on the organization); 
Table 4.2 Stakeholder classifications

\begin{tabular}{|c|c|c|}
\hline No. & Criterion & Stakeholder Categories \\
\hline 1. & Company property & $\begin{array}{l}\text { - Shareholding stakeholders } \\
\text { - Non-shareholding stakeholders }\end{array}$ \\
\hline 2. & Company appurtenances & $\begin{array}{l}\text { - Internal (endogenous) stakeholders } \\
\text { - External (exogenous) stakeholders }\end{array}$ \\
\hline 3. & $\begin{array}{l}\text { Number of components of } \\
\text { stakeholder }\end{array}$ & $\begin{array}{l}\text { - Individual stakeholders } \\
\text { - Group (organizational) stake- } \\
\text { holders }\end{array}$ \\
\hline 4. & $\begin{array}{l}\text { Market implications of the } \\
\text { stakeholder (Lawrence, 2010) }\end{array}$ & $\begin{array}{l}\text { - Market stakeholders } \\
\text { - Non-market (activists) stake- } \\
\text { holders }\end{array}$ \\
\hline 5. & $\begin{array}{l}\text { Duration of stakeholders' } \\
\text { involvement }\end{array}$ & $\begin{array}{l}\text { - Permanent stakeholders } \\
\text { - Occasional stakeholders }\end{array}$ \\
\hline 6. & Nature of stakeholders' interest & $\begin{array}{l}\text { - Private stakeholders } \\
\text { - Public stakeholders }\end{array}$ \\
\hline 7. & $\begin{array}{l}\text { Legal basis of stakeholders' } \\
\text { relationship with organization } \\
\text { (Gautrey, 2013) }\end{array}$ & $\begin{array}{l}\text { - Contractual stakeholders } \\
\text { - Community stakeholders }\end{array}$ \\
\hline 8. & $\begin{array}{l}\text { Stakeholder nature of interests and } \\
\text { area of influence (Chandler \& } \\
\text { Werther, 2014) }\end{array}$ & $\begin{array}{l}\text { - Organizational stakeholders } \\
\text { - Economic stakeholders } \\
\text { - Societal stakeholders }\end{array}$ \\
\hline 9. & $\begin{array}{l}\text { Stakeholder contribution to the } \\
\text { company's value generation } \\
\text { (Calkoen, 2017) }\end{array}$ & $\begin{array}{l}\text { - Key stakeholders } \\
\text { - Ancillary stakeholders }\end{array}$ \\
\hline 10. & $\begin{array}{l}\text { Number of persons that represent } \\
\text { an organizational stakeholder }\end{array}$ & $\begin{array}{l}\text { - Single organizational representative } \\
\text { - Multi-organizational representative }\end{array}$ \\
\hline
\end{tabular}

- urgency (the degree to which an individual or group stakeholder claim should generate immediate action from organization managers).

These attributes provide salience to the stakeholder, which could be defined as how visible or prominent a stakeholder is to the organization's manager.

By combining these three attributes, seven different types of stakeholders emerge (see Figure 4.2).

Dormant, discretionary, and demanding stakeholders, which possess only one attribute, form the low-salience classes. For them, the term "latent" stakeholders is used, because their influence upon the organization is very small.

Dominant, dangerous, and dependent stakeholders, which possess two attributes, form the moderate-salience classes. For them, the term "expectant stakeholders" is employed, because they are stakeholders who "expect something" from the organization.

Definitive stakeholders, which have three attributes, represent the highly salient stakeholders, having the most influence on the organization. 


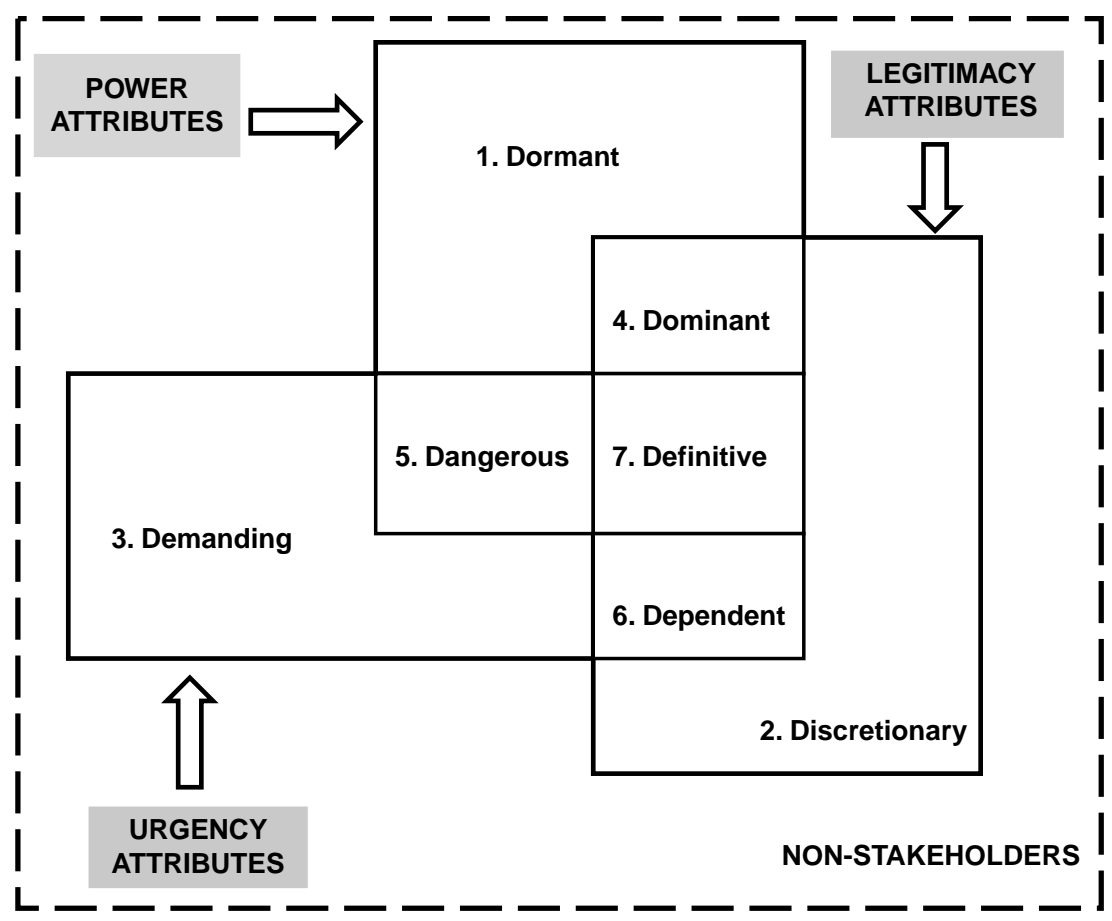

Figure 4.2 Stakeholder typology.

Adapted from "Toward a theory of stakeholders identification and salience: Defining the principle of who and what really counts" by R. K. Mitchell, B. R. Agle, \& D. J. Wood, 1997, Academy of Management Review, 22(4), 874. Retrieved from https://www.jstor.org/ stable/259247?seq=1\#metadata_info_tab_contents

The model is based on the idea that the more salient stakeholders are given priority by the organization managers in terms of communication and actions. Normally, the less-salient stakeholders have less priority in relationships with company managers. Without any doubt, the stakeholder salience model is very helpful for organization managers in the identification and prioritization of internal and external stakeholders, although the three attributes taken into consideration do not cover all major characteristics of stakeholders in their rapport with the organization.

Other specialists, such as Bryson, Patton, and Bowman (2011), promote the evaluation of stakeholders based on many more elements:

- stakeholders' interests

- stakeholders' needs

- stakeholders' concerns

- stakeholders' power

- stakeholders' priorities

- stakeholders' perspectives 
In the authors' opinion, analysis of these characteristics using special techniques - Utilization Focused Evaluation (UFE), SMART, BART, Force Field Analysis, Dennis Triangle Steering Parameters, Time Management Matrix - provides credible stakeholder evaluations to the organization.

In the last few years, specialists have discovered more sophisticated variables in order to evaluate and prioritize stakeholders, such as perceived sustainability of fulfilling stakeholders' interests for companies and assumed costs for (potential) investors' investment intentions (Schwarzmüller, Brosi, \& Welpe, 2017).

Company managers, taking into consideration the results of the evaluation, could use different communication strategies. Coghlan (2016) recommends three types - informational, persuasive, and dialogue strategies (see Figure 4.3).

Stakeholder identification, prioritization, and communication approaches contribute to the increase of the potential effectiveness of managers in dealing with multiple and various company stakeholders, in an increasingly VUCA environment.

\section{Laws and Principles Regarding Organization Stakeholders}

In the approach of any field in economy and in management, there are gradual steps ahead, reflecting the accumulation of information and knowledge, the enhancement and the deepening of analysis, the development of special competences and the vision of the involved specialists, etc. In fact, it is a problem of the maturation of the specific approach

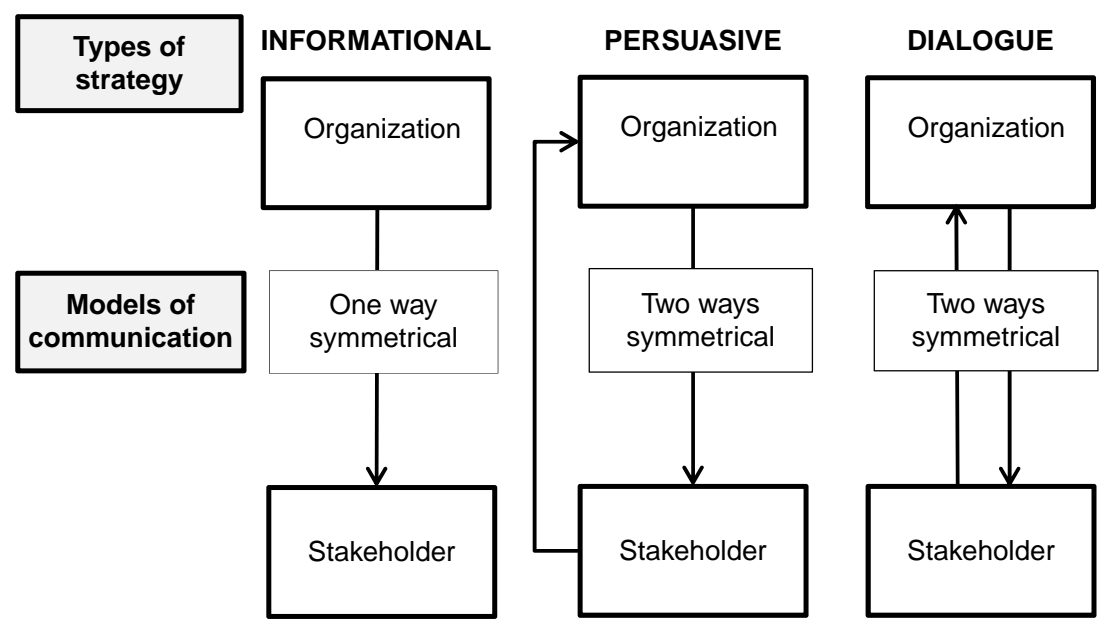

Figure 4.3 Types of communicational strategies.

Adapted from Inside organizations: Exploring organizational experience (p. 70), by D. Coghlan, 2016, Sage Publications. 
to the respective field. One significant expression of the maturation is the elaboration of specific laws, principles, and axioms. Of course, these elements are valuable for the stakeholder field too.

Recently, two specialists - Garcia-Castro and Francoeur (2016) formulated three laws regarding company stakeholders. The laws present two significant dimensions:

- business dimension, because they are focused on company performance, taking into consideration the investment size and allocation of the investments in the stakeholders. They treat the stakeholders from the perspective of their impact on value creation and are based on the premise that there is not a monotonic relationship between investment in stakeholders and firm performance;

- management dimension, because the laws are focused on the main objective of the company's management - enhancing the organization's performance - and legal requirements should be implemented through the managers decisions.

We present the stakeholder laws exactly as formulated by Castro and Francoeur:

I Law of stakeholder core balance: A minimum investment in each primary stakeholder is a necessary condition for achieving high firm performance.

II Law of decreasing marginal returns to stakeholder investments: There are decreasing marginal returns, and beyond some point, negative returns to marginal increases in investments in any single stakeholder group.

III Law of contingent performance: The optimal investment in a stakeholder (within the lower and upper bounds) is contingent on firm strategy, industry features and national/legal factors.

The value of the stakeholder laws has been demonstrated empirically by an analysis of 1,060 multinational companies, which is a representative sample.

In our opinion, the stakeholder laws represent - at least from a pragmatic point of view - an outstanding contribution to the management of company stakeholders. We support our statement with the following four arguments:

a laws refer to the main stakeholders from the company point of view. The role and influence of the important stakeholders is appreciated based on their contribution to the company performance and sustainability. Other characteristics of the stakeholder - legitimacy, power, urgency, size, etc. - are taken into consideration only to 
the extent to which they contribute to the stakeholder impact on the company's performance;

b laws are formulated in a systemic approach, because they take into consideration all major stakeholders, bearing in mind the interrelations among them. In the second argument, the laws refer to the general performance of the company, regarded as a system;

c stakeholder laws promote an equilibrated approach regarding the size of the investments in stakeholders and the share allocated to the major stakeholders. The authors propose establishing some lower and upper limits to effective investment in stakeholder groups. They argue that a minimum investment should be made in every major stakeholder and a disproportionate high investment in certain stakeholders should be avoid;

d stakeholder laws require stakeholders' investments to be differentiated in every organization, taking into consideration the impact of firm strategy, industry features and national/legal factors. Such contextual thinking is an essential element in order to ensure the realism of the stakeholder approach, depending on the specificity of each company, reflected in its strategy and the customized particular conditions in the involved industry and national environment.

Based on these arguments, we feel that the stakeholder laws formulated by Castro and Francoeur are very useful for fulfilling a performant management in companies.

In the same category, of the essential elements regarding the pragmatic management approach of company stakeholders, the principles of stakeholder management are included.

Without any doubt the best known are "the Clarkson principles" (The Clarkson Centre for Business Ethics, 1999). Max Clarkson's seven principles are the following:

Principle 1: Managers should acknowledge and actively monitor the concerns of all legitimate stakeholders and should take their interests appropriately into account in decision-making and operations.

Principle 2: Managers should listen to and openly communicate with stakeholders about their respective concerns and contributions and about the risks that they assume because of their involvement with the corporation.

Principle 3: Managers should adopt processes and modes of behaviour that are sensitive to the concerns and capabilities of each stakeholder constituency.

Principle 4: Managers should recognize the interdependence of efforts and rewards among stakeholders and should attempt to achieve a fair 
distribution of the benefits and burdens of corporate activity among them, taking into account their respective risks and vulnerabilities.

Principle 5: Managers should work cooperatively with other entities, both public and private, to ensure that risks and harms arising from corporate activities are minimized and, where they cannot be avoided, appropriately compensated.

Principle 6: Managers should avoid altogether activities that might jeopardize inalienable human rights (e.g. the right to life) or give rise to risks that, if clearly understood, would be patently unacceptable to the relevant stakeholders.

Principle 7: Managers should acknowledge the potential conflicts between (a) their own role as corporate stakeholders and (b) their legal and moral responsibilities for the interests of stakeholders and should address such conflicts through open communication, appropriate reporting and incentive systems, and, where necessary, third-party review.

These principles, which refer to all legitimate company stakeholders, have been largely accepted by stakeholder specialists (e.g. Buchholtz \& Carroll, 2012; Clarkson, Donaldson, Preston, \& Brooks, 2000; Donaldson, 2002). According to Thomas Donaldson, Clarkson's principles have contributed "to develop[ing] a broad conception of corporation as a vehicle for advancing the interests of, and responding to the concerns of, multiple and diverse stakeholders" (Donaldson, 2002). The Clarkson principles deal with seven major types of actions regarding company stakeholders, which are able to contribute to a large extent to the rationale and effective relationships with them, having a notable ethic dimension. For this reason, they have been intensively used in the analysis of the USA corporation management during the 2009-2010 crisis.

The Clarkson principles deal with the whole management processes of corporation stakeholders.

In the stakeholder literature, sets of principles regarding especially stakeholder engagement have also been published, largely disseminated by the Internet. For example, Gautrey (2013) formulated seven guiding principles of stakeholder engagement:

1 Identify the stakeholders;

2 Focus on stakeholders who have the most power to help hinder your goal;

3 Be very clear about what you want from each stakeholder;

4 Connect stakeholders' interests to your goals;

5 Increase your goal's priority;

6 Don't always deal directly with stakeholders;

7 Attain enough agreement to secure your goal. 
The stakeholder management laws and principles represent a later stage in the development of the stakeholder theory and practice. They represent very helpful knowledge for the systemic approach to the very complex and difficult aspects associated with organization stakeholder management in a VUCA environment.

\section{The Corporate Governance-Stakeholder Management Relationship}

Corporate governance has appeared as an answer to the delimitation between company management and its owners. Traditionally, a company was managed by members of the owners' family. The business, technological, managerial, scientific, financial, etc. mutations, during the second part of the last century, generated the need for professional company management, especially for corporations, and large and medium enterprises, organized frequently as a shareholders' organization. As a result, quite often shareholder companies have hired professional managers in the top company positions. Between the company shareholders and managers, new types of managerial and business relations have developed. Corporate governance represents a complex approach - managerial, juridical, and business - used in order to manage the company according to the shareholders' interests. Corporate governance represents a set of rules and stimulants used by the shareholders and company management in order to maximize the company profit and value for the shareholders.

Some companies - like General Motors in 1992 - have faced scandals in their corporate governance. In order to solve such problems, to ensure transparency, accountability, fairness, and responsibility, the Cadbury Code was written and the OECD has produced a model code for corporate governance, which is used in many countries to elaborate national versions.

Corporate governance has contributed to a certain extent to more responsible management of companies, but there have been, and still are, many difficulties and challenges. What happened during the 2008-2009 crisis in the USA with some corporations like Enron provides the relevant facts in this respect.

In a comprehensive book (Calkoen, 2017) regarding the screening of corporate governance, specialists identified a set of "hot topics" in this field:

- transparency

- reporting

- compliance

- IT

- accountability and liability

- short termism versus long-run strategy

- shareholder activism 
- stakeholders

- sustainability

- measures against climate change

- trust

Other studies have found other major limitations and difficulties in corporate governance practice like: negative effects of large shareholders with excess control rights (Boateng \& Huang, 2017), top managers' engagement in misconduct, such as illegal insider trading, illegal stock option backdating, bribery, and financial manipulation (Connelly, Shi, \& Zyung, 2017), shareholders' coalitions that serve as an instrument for dominant shareholders to extract private benefits (López-Iturriaga and Santana-Martín, 2015).

An analysis conducted in 2015 by Grant Thornton Institute, regarding the practice of corporate governance in 312 FTSE representative companies from Great Britain, showed a very complex situation raising many questions marks. They found that only 11 companies, which means less than $4 \%$ from all organizations, have truly embraced the spirit of corporate governance (Grant Thornton, 2015).

There are many studies (Fauver, Hung, Li, \& Taboada, 2017; Gangi \& D’Angelo, 2017; Lafarre, 2017; Salvioni \& Gennari, 2016) that increase the need to improve corporate governance significantly, but for the most part, this is mainly from the perspective of shareholders, who represent only one category of stakeholders. Moreover, according to an analysis carried out by a group of specialists (Schwarzmüller, Brosi, Stelkens, Spörrle, \& Welpe, 2017), companies regularly have to address opposing interests from their stakeholding and non-shareholding stakeholding groups.

As regards corporate governance, we believe it is necessary to outline two aspects:

a Elements described in the previous sections indicate that corporate governance focused on the primordiality of shareholders' interests has not been able to accomplish its objectives: transparency, accountability, fairness, and responsibilities. Even the shareholders' interests have not been sufficiently protected;

b Corporate governance as a rule does not try and does not take into consideration the interests, the stakes and the impact of the company's main stakeholders, although quite a few specialists ask this to be done. For this reason, corporate governance is not able to use the potential of all main company stakeholders and - as a consequence to generate sustainability for the company and for themselves. 
The stakeholder theory provides the framework for overcoming the essential limitations of the corporate governance and shareholders' approach.

There have been several studies in recent decades that contain consistent proposals regarding the development of stakeholder theory and practice, so as to ensure the company's sustainability and the stakeholders' potential valorization. For example, a group of renowned specialists - Mitchell, Weaver, Agle, Bailey, and Carlson (2015) - proposed "develop[ing] a multi-objective corporation as a means of enabling a greater range of management decisions so as to permit more direct corporate engagement in the diverse goals of various stakeholders". Their approach is built on the stakeholder agency framework, wherein corporate actions reflect the outcome of an intercorporate marketplace.

Another study (Mitchell, Van Buren III, Greenwood, \& Freeman, 2015) states that

because present accounting theory and practice does not address the decision-making needs of all stakeholders, who are at risk due to the activities of an organization, it proposes to develop a transdisciplinary theory of value creation stakeholder accounting (VCSA) based on stakeholder risk-sharing, as a superior rationale of stakeholder inclusion.

They introduce "value creation" stakeholder partnerships (VCSPs) as a promising mechanism for the implementation of VCSA, which emerges from distinguishing proprietary-convention (partnership) from entityconvention (corporate) accounting.

Besides the studies dealing with stakeholders, other approaches have been elaborated in order to provide solutions for the present corporate governance problems. "Creating Shared Value (CSV)" by Porter and Kramer (2011) is one that is very popular. Shared value consists in "policies and operating practices that enhance the competitiveness of a company while simultaneously advancing the economic and social conditions in the communities in which it operates". By value they mean benefits relative to cost, not benefits accrued alone. In the authors' opinion, "CSV can give use to the next major transformation of business thinking”. In another study, a group of specialists (Crane, Palazzo, Spence, \& Matten, 2014), although they appreciated Porter and Kramer's ideas, expressed doubts, with serious arguments, from a theoretical and pragmatic point of view. ${ }^{4}$ Crane et al. (2014) believed that "stakeholder theory is probably the long-lasting approach to reconceptualizing the firm as a multi-purpose entity". "Stakeholder theory is fundamentally a theory about how business works at its best and how 
it could work. It is descriptive, prescriptive and instrumental all at the same time, and as Donaldson and Preston have argued, it is managerial" (Freeman et al., 2010).

\section{Our Proposals Regarding the Development of a New Stakeholder Management Approach}

In our opinion, two main conclusions can be formulated regarding the situation of stakeholder theory and practice. First, the stakeholders' approach, after more than half a century of history, has demonstrated that it is valuable and could generate multiple benefits for companies, their stakeholders, and the society. Second, the stakeholder theory and practice should be developed consistently and rapidly, in order to be able to generate more benefits for all stakeholders, taking into consideration the deep and rapid contextual mutations modified - to some extent -by the COVID-19 pandemic. So far, the potential of company stakeholders has been valorized only to a small extent by company management.

We propose several elements as a foundation for further development of the stakeholder management approach (see Figure 4.4). Our proposals deal only with pragmatic managerial aspects of the stakeholder approach.

A Expanding the use of the stakeholder approach by corporations, big investment projects and public-private partnerships - the current situation in the stakeholder theory and practice - to all types of companies. The company operations and performance, notwithstanding size, depend decisively on the main stakeholder-owners (shareholders), managers, executants, clients, suppliers, bankers, etc. As such, there are no reasons for a company to ignore its stakeholders. Of course, when the company size and the complexity increase, the dependence of its performance and sustainability on the stakeholders increases too. In our opinion, the stakeholders' frequency, intensity, and impact on the company require a managerial approach focused on the stakeholders, using new management and business mechanisms - not only for corporation and big projects but also for large and medium-sized companies. Small companies and micro-companies should also be reoriented towards exploiting stakeholders' potential, but without it always being necessary to create specialized business and managerial mechanisms.

B Systemic stakeholders' approach taking into consideration all major organization stakeholders. It is necessary to change the present situation, characterized by the placement in the foreground of shareholders and managers, followed, at a certain distance, by some clients and suppliers. In order to ensure a realistic approach on the part of stakeholders, to have effective communication and an 


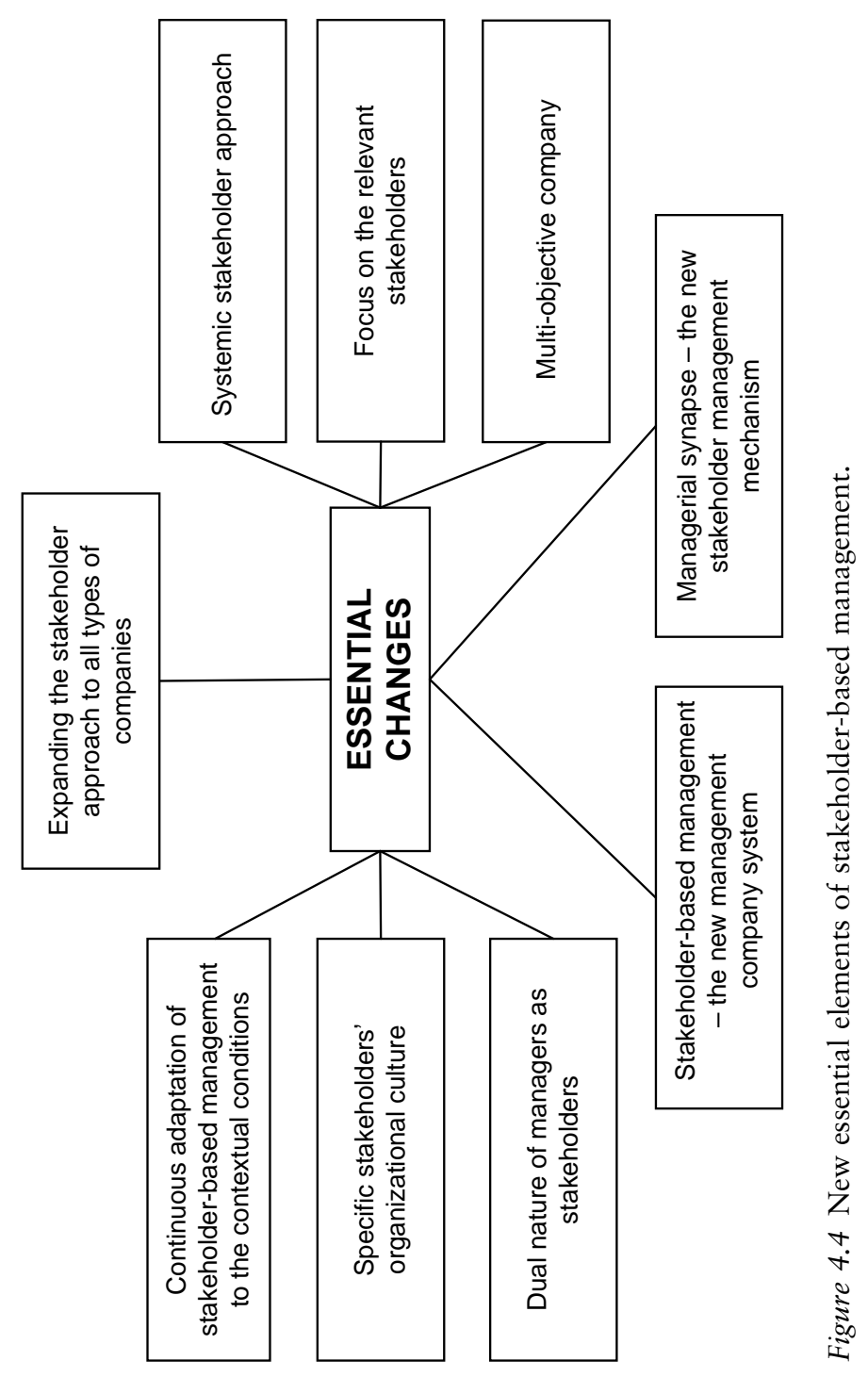


efficient work relationship, it is necessary to take into consideration the diversity of their goals and their characteristics, and the coopetition among them. Relationships with company stakeholders should be based on win-win negotiations with each main stakeholder, subordinate to the company's sustainability.

C Company stakeholders should be treated in a differentiated manner, taking into consideration the relevance for the organization. Stakeholder relevance should be evaluated from two points of view:

- the main stakeholder characteristics - power, legitimacy, urgency, cost involved, impact, etc.

- the correlation between company strategy and policies and the stakeholder capacity and contribution to implement them successfully.

We believe that often the second aspect is more important for company performance and sustainability than the first. In order to avoid making mistakes, both aspects should be taken correlatively into consideration.

D The company should be approached as an entity with multiple strategic objectives, determined according to the interests of the relevant stakeholders. Usually, the company's multi-objective should be multi-dimensional - financial, technical, social, ecological, etc. It is recommended that strategic company objectives should be focused on the company and the relevant stakeholders' long-term sustainability. Such objectives motivate the relevant stakeholders to be involved and productive and, concomitantly, to promote in the company a long-term approach that is beneficial for all. A multi-objective approach and the way to plan it should generate stakeholder synergy.

E Creation in the company of specific managerial business mechanisms at the level of each relevant stakeholder, in order to exploit at a high level the stakeholder potential and to generate effective win-win relationships. In this study, we propose such a mechanism named by us "managerial synapse" (see Chapters 5 and 6).

F Remodelling of the entire company management through a new management system capable of managing efficiently the entity relationships with all relevant stakeholders. This system should be designed using the performant concepts and methods provided by the top professional management. Such a system should be innovative, flexible, and dynamic, related to the present fast contextual changes. We call it a "stakeholder-based management system", and in this book, we will make a proposal with the main constructive and functional parameters (see Chapters 9, 10 and 11).

G Managers who make a decisive contribution to the design, implementation, and functioning of the managerial synapse and 
stakeholder-based management system have a dual, very complex, nature. The dual nature of managers means:

- managers represent the company, and they have a decisive role in each relevant stakeholder identification, evaluation, communication, and work together. Managers are key factors in the design and implementation of the managerial synapse and stakeholder-based management system;

- managers are themselves relevant company stakeholders, with their own interests and stakes, which are partially different from those of their company.

Between the two sides of managers' nature, there are both convergent and divergent elements. The way in which these two managerial sides are harmonized, in the processes of designing the managerial synapse and stakeholder-based management system, depends to a large extent on the company and stakeholders' performance.

$\mathrm{H}$ New stakeholder-based management involves a new organizational culture, based on the approach of the company as an open system, which is centred on the relevant internal and external stakeholders. Organizational culture through the values promoted, through the individual and organizational behaviours incorporated, contributes greatly to the development of the stakeholders' cohesion, attachment, and implication in the companies' activities and performances. It is essential in a company "to build trust capital" among the relevant stakeholders.

I A new stakeholder-based management system should be designed taking into consideration the megashifts in the company environment:

- Increase of the environment's complexity, dynamism, and volatility;

- Digitalization of the socio-economic procesess;

- Work intellectualization;

- Internationalization of all activities;

- Multiculturalization of the labour force;

- Nanotechnologization and biotechnologization;

- Comprehensive networking in the society and economy;

- Sustainable ecologization;

- Intensification and diversification of state interventions;

- Development of a powerful educational-formative dimension;

- Multidimensional remodelling of the markets.

The recent challenges, difficulties, and opportunities generated by the COVID-19 pandemic should receive special attention in the creation of the new management company system based on stakeholders. This 
management system will be performant if it succeeds in exploiting to a high degree the most important resource of the smart economy - knowledge and achieves comprehensive and accelerated digital transformations, related to the last evolutions of the present intensive digitalization.

The elements presented are essential for the transition from the current situation in companies to the next stage focused on the new stakeholder approach. The general framework of this transition is exhibited in Figure 4.5.

This framework indicates the two axes of the transition:

- company axis, indicating the change from a company centred on shareholders to an entity centred on stakeholders;

- management axis, revealing the shift from corporate governance to stakeholder-based management.

Between these two axes, there are many interdependencies and influences, which will be analyzed in the following chapters from several perspectives.

The new company management system, based on the relevant stakeholders, exceeds certain limitations of the company salient stakeholders' approach, like being largely static, short-term oriented and firm centred.

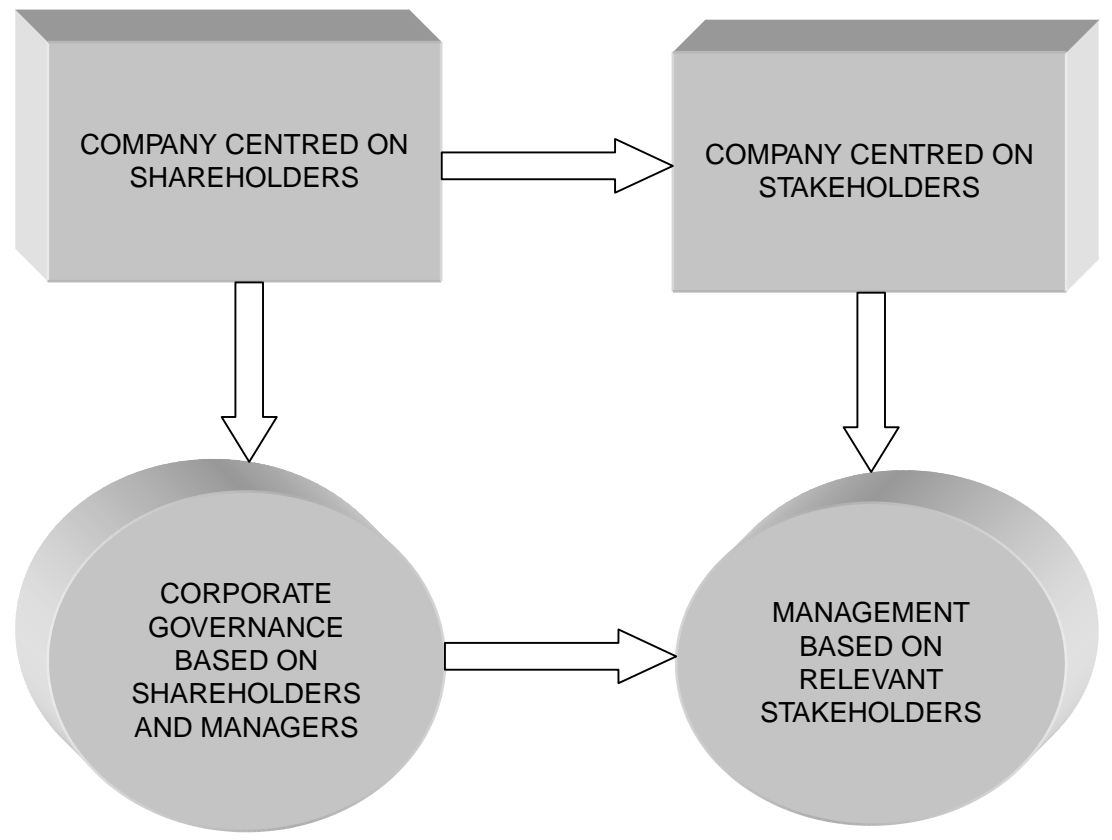

Figure 4.5 The framework of the transition to stakeholder-based management. 


\section{Notes}

1 It is even a tendency to expand normative perspective from corporation level to other types of entities. In a very interesting paper, Sandra Waddock considers that "humans, institutions, enterprises, other living beings, and ecological systems are all stakeholders of a core focal entity - the Earth, conceived as a living system of Gaya. See Waddock, S. (2011), We are all stakeholders of Gaia: A normative perspective on stakeholder thinking. Organization \& Environment, 24(2), 192-212. doi:10.1177/108602 6611413933

2 This is a standard classification. At the level of each company, depending on its specificity, certain primary stakeholders could be secondary stakeholders, and vice versa.

3 When they are not strategic, they enter the secondary stakeholders category.

4 Michael Porter and Mark Kramer have formulated a feedback to the comments of these specialists. See a response to Crane et al.'s article by Michael Porter and Mark Kramer (2014) in California Management Review, 56(2), between pages 149 and 151. doi:10.1525/cmr.2014.56.2.130

\section{References}

Baden, D. (2016). A reconstruction of Carroll's pyramid of corporate social responsibility for 21st century. International Journal of Corporate Social Responsibility, 1(8), 1-15. doi:10.1186/s40991-016-0008-2

Berman, S. L., \& Johnson-Cramer, M. E. (2017). Stakeholder theory: Seeing the field through the forest. Business \& Society, 58(7), 1358-1375. doi:10.1177/ 0007650316680039

Boateng, A., \& Huang, W. (2017). Multiple large shareholders, excess leverage and tunneling: Evidence from an emerging market. Corporate Governance: An International Review, 25(1), 58-74. doi:10.1111/corg.12184

Bryson, J., Patton, M. Q., \& Bowman, R. A. (2011). Working with evaluation stakeholders: A rationale, step-wise approach and toolkit. Evaluation and Program Planning, 34(1), 1-12. doi:10.1016/j.evalprogplan.2010.07.001

Buchholtz, A. K., \& Carroll, A. B. (2012). Business and society: Ethics and stakeholder management (8th ed.). Mason, OH: South-Western Cengage Learning.

Calkoen, W. J. L. (2017). The corporate governance review (7th ed.). London, UK: Law Business Research Ltd.

Carroll, A. B. (1979). A three-dimensional conceptual model of corporate social performance. Academy of Management Review, 4(4), 497-505. doi:10.2307/ 257850

Carroll, A. B. (1991). The pyramid of corporate social responsibility: Toward the moral management of organizational stakeholders. Business Horizons, 34(4), 39-48. Retrieved from https://www.researchgate.net/publication/4883660_The_ Pyramid_of_Corporate_Social_Responsibility_Toward_the_Moral_

Management_of_Organizational_Stakeholders 10.1016/0007-6813(91)90005-G

Chandler, D., \& Werther, B. W. (2014). Strategic corporate social responsibility: Stakeholders, globalization and sustainable value creation (3rd ed.). Los Angeles, CA: Sage Publications. 


\section{2}

Chartered Management Institute. (2013). Stakeholder analysis and management checklist 234. Retrieved from https://mmclearning.com/elearningdemo/cmi/ docs/Stakeholder_Analysis\&Management_Checklist_234.pdf

Clarkson, M. B. E., Donaldson, T., Preston, L. E., \& Brooks, L. J. (2000). Principles of stakeholder management. Retrieved from http://www.rotman. utoronto.ca/ stake/Principles.htm

Coghlan, D. (2016). Inside organizations: Exploring organizational experience. London, UK: Sage Publications. doi:10.4135/9781526402424

Connelly, B. L., Shi, W., \& Zyung, J. (2017). Managerial response to constitutional constrains on shareholder power. Strategic Management Journal, 38(7), 1499-1517. doi:10.1002/smj.2582

Crane, A., Palazzo, G., Spence, L. J., \& Matten, D. (2014). Contesting the value of creating shared value. California Management Review, 56(2), 130-153. doi: $10.1525 / \mathrm{cmr} .2014 .56 .2 .130$

Donaldson, T. (2002). The stakeholder revolution and the Clarkson principles. Business Ethics Quarterly, 12(2), 107-111. doi:10.5840/beq200212211

Donaldson, T., \& Preston, L. E. (1995). The stakeholder theory of the corporation: Concepts, evidence, and implications. Academy of Management Review, 20(1), 65-91. Retrieved from https://www.jstor.org/stable/258887? seq=1\#metadata_info_tab_contents. doi:10.2307/258887

Elias, A. A., \& Cavana, R. Y. (2000). Stakeholder analysis for systems thinking and modeling. Retrieved from https://pdfs.semanticscholar.org/b52e/0594841 aeb6841e4d8c8e0e5b2cd2564385c.pdf?_ga=2.5988149.703572193.155301 8223-2027391651.1553018223

Fauver, L., Hung, M., Li, X., \& Taboada, A. G. (2017). Board reforms and firm value: Worldwide evidence. Journal of Financial Economics, 125(1), 120-142. doi:10.1016/j.jfineco.2017.04.010

Fontaine, C., Haarman, A., \& Schmid, S. (2006). The stakeholder theory. Retrieved from https://pdfs.semanticscholar.org/606a/828294dafd62aeda92 a77bd7e5d0a39af56f.pdf

Freeman, R. E. (1984). Strategic management: A stakeholder approach. Boston, MA: Pitman.

Freeman, R. E. (2017). Five challenges to stakeholder theory: A report on research in progress. In D. M. Wasieleski \& J. Weber (Eds.), Stakeholder Management - Business and Society 360 (pp. 1-20). Bingley, UK: Emerald Publishing Limited.

Freeman, R. E., Harrison, J. S., Wicks, A. C., Parmar, B. L., \& De Colle, S. (2010). Stakeholder theory: The state of art. New York: Cambridge University Press.

Friedman, A. L., \& Miles, S. (2002). Developing stakeholder theory. Journal of Management Studies, 39(1), 1-21. doi:10.1111/1467-6486.00280

Gangi, F., \& D'Angelo, E. (2017). "Make" or "buy" the choice of governance modes for corporate social responsibility projects from a stakeholder management perspective. International Business Research, 10(8), 80-92. doi:10.5539/ ibr.v10n8p80

Garcia-Castro, R., \& Aguilera, R. V. (2015). Incremental value creation and appropriation in a world with multiple stakeholders. Strategic Management Journal, 36(1), 137-147. doi:https://doi.org/10.1002/smj.2241 
Garcia-Castro, R., \& Francoeur, C. (2016). When more is not better: Complementarities, costs and contingencies in stakeholder management. Strategic Management Journal, 37(2), 406-424. doi:10.1002/smj.2341

Gautrey, C. (2013, June 11). Seven guiding principles of stakeholder. Association for Talent Development. Retrieved from https://www.td.org/insights/sevenguiding-principles-of-stakeholder-engagement

Grant Thornton. (2015). Corporate governance review 2015: Trust and integrity - Loud and clear? Retrieved from https://www.grantthornton.co.uk/ globalassets/1.-member-firms/united-kingdom/pdf/publication/2015/uk-corporate-governance-review-and-trends-2015.pdf

Harrison, J. S., \& Wicks, A. (2013). Stakeholder theory, value and firm performance. Business Ethics Quarterly, 23(1), 97-124. doi:10.5840/beq20132314

Kumar, V., \& Rajan, B. (2017). What's in it for me? The creation and destruction of value for firms from stakeholders. Journal of Creation Value, 3(2), 142-156. doi:10.1177/2394964317723449

Lafarre, A. (2017). The AGM in Europe: Theory and practice of shareholders behaviour. Bingley, UK: Emerald Publishing Limited.

Lawrence, A. T. (2010). Managing disputes with non market stakeholders: Wage a fight, withdraw, wait, or work it out? California Management Review, 53(1), 90-113. doi: $10.1525 / \mathrm{cmr} .2010 .53 .1 .90$

Levenson, A. (2020). A long time until the economic new normal. MIT Sloan Management Review. Retrieved from https://sloanreview.mit.edu/article/along-time-until-the-economic-new-normal

López-Iturriaga, F. J., \& Santana-Martín D. J. (2015). Do shareholder coalitions modify the dominant owner's control? The impact on dividend policy. Corporate Governance: An International Review, 23(6), 519-533. doi:10.1111/corg.12126

Miles, S. (2017). Stakeholder theory classification, definitions and essential contestability. In D. M. Wasieleski \& J. Weber (Eds.), Stakeholder Management - Business and Society 360 (pp. 21-47). Bingley, UK: Emerald Publishing Limited.

Mitchell, R. K., Agle, B. R., \& Wood, D. J. (1997). Toward a theory of stakeholders identification and salience: Defining the principle of who and what really counts. Academy of Management Review, 22(4), 853-886. Retrieved from https://www.jstor.org/stable/259247?seq=1\#metadata_info_tab_contents. doi: $10.2307 / 259247$

Mitchell, R. K., Van Buren III, H. J., Greenwood M., \& Freeman, R. E. (2015). Stakeholder inclusion and accounting for stakeholders. Journal of Management Studies, 52(7), 851-877. doi:10.1111/joms.12151

Mitchell, R. K., Weaver, G. R., Agle, B. R., Bailey, A. D., \& Carlson, J. (2015). Stakeholder agency and social welfare: Pluralism and decision making in the multi-objective corporation. Academy of Management Review, 41(2), 252-275. doi:10.5465/amr.2013.0486

Narayandas, D., Hebbar, V., \& Li, L. (2020). Lessons from Chinese companies' response to Covid-19. Harvard Business Review. Retrieved from https:// hbr.org/2020/06/lessons-from-chinese-companies-response-to-covid-19

Porter, M. E., \& Kramer, M. R. (2011). Creating shared value. Harvard Business Review. Retrieved from https://hbr.org/2011/01/the-big-idea-creating-sharedvalue 
Radjou, N. (2020). The rising frugal economy. MIT Sloan Management Review. Retrieved from https://sloanreview.mit.edu/article/the-rising-frugal-economy/

Romeo, J., Moukanas, H., \& Rung, G. (2020). The age of accelerating strategy breakthroughs. MIT Sloan Management Review. Retrieved from https:// sloanreview.mit.edu/article/the-age-of-accelerating-strategy-breakthroughs/

Salvioni, D., \& Gennari, F. (2016). Corporate governance, ownership and sustainability. Corporate Ownership \& Control, 13(2), 606-612. doi:10.22495/ cocv13i2c3p9

Schwarzmüller, T., Brosi, P., Stelkens, V., Spörrle, M., \& Welpe, I. M. (2017). Investors' reactions to companies' stakeholder management: The crucial role of assumed costs and perceived sustainability. Business Research, 10(1), 79-96. doi:10.1007/s40685-016-0040-9

Schwarzmüller, T., Brosi, P., \& Welpe, I. M. (2017). Führung 4.0 - Wie die Digitalisierung Führung verändert. In A. Hildebrandt \& W. Landhäußer (Eds.), CSR und Digitalisierung: Der digitale Wandel als Chance und Herausforderung für Wirtschaft und Gesellschaft (pp. 617-628). Berlin, Germany: Springer Gabler. doi:10.1007/978-3-662-53202-7_43

Steurer, R. (2006). Mapping stakeholder theory anew: From a "theory of the firm" to three perspectives on business-society relations. Business Strategy and the Environment, 15(1), 55-69. doi:10.1002/bse.467

Tarabishy A. E., \& Carayannis, E. (2020, September 12). Democratization of knowledge. International Council for Small Business. Retrieved from https:// icsb.org/democratizationofknowledge/

Teece, D. J., Raspin, P. G., \& Cox, D. R. (2020). Plotting strategy in a dynamic world. MIT Sloan Management Review. Retrieved from https://sloanreview. mit.edu/article/plotting-strategy-in-a-dynamic-world/?gclid=Cj0KCQiAst2 BBhDJARIsAGo2ldVOCiF24Hjd9rFWzT7VPsrIVT7GiIgyPbEpHt0NIQbb4 uFpMA_8oOsaAlHvEALw_wcB

The Clarkson Centre for Business Ethics. (1999). Principles of stakeholders management: The Clarkson principles. Toronto, CA: The Clarkson Centre for Business Ethics.

Wheeler, D., \& Sillanpää, M. (1997). The stakeholder corporation: A blue print for maximizing stakeholder value. London, UK: Pitman Publishing.

Wheeler, D., \& Sillanpää, M. (1998). Including the stakeholders: The business case. Long Range Planning, 31(2), 201-210. doi:10.1016/S0024-6301(98) 00004-1

World Economic Forum. (2020). The global risk report 2020. Retrieved from http://www3.weforum.org/docs/WEF_Global_Risk_Report_2020.pdf

Zakhem, A., \& Palmer, D. E. (2017). Normative stakeholder theory. In D. M. Wasieleski \& J. Weber (Eds.), Stakeholder Management - Business and Society 360 (pp. 49-73). Bingley, UK: Emerald Publishing Limited. 